\title{
REALIGNMENT, REGION, AND RACE
}

\author{
Presidential Leadership and \\ Social Identity
}




\title{
REALIGNMENT, REGION, AND RACE
}

\section{Presidential Leadership and Social Identity}

\author{
BY
}

GEORGE R. GOETHALS

Jepson School of Leadership Studies,

University of Richmond, USA

\section{emerald PUBLISHING}

United Kingdom - North America - Japan India - Malaysia - China 
Emerald Publishing Limited

Howard House, Wagon Lane, Bingley BD16 1WA, UK

First edition 2018

Copyright (C) 2018 Emerald Publishing Limited

Reprints and permissions service

Contact: permissions@emeraldinsight.com

No part of this book may be reproduced, stored in a retrieval system, transmitted in any form or by any means electronic, mechanical, photocopying, recording or otherwise without either the prior written permission of the publisher or a licence permitting restricted copying issued in the UK by The Copyright Licensing Agency and in the USA by The Copyright Clearance Center. Any opinions expressed in the chapters are those of the authors. Whilst Emerald makes every effort to ensure the quality and accuracy of its content, Emerald makes no representation implied or otherwise, as to the chapters' suitability and application and disclaims any warranties, express or implied, to their use.

British Library Cataloguing in Publication Data

A catalogue record for this book is available from the British Library

ISBN: 978-1-78743-792-0 (Print)

ISBN: 978-1-78743-791-3 (Online)

ISBN: 978-1-78743-980-1 (Epub)

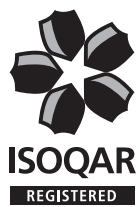

Certificate Number 1985 ISO 14001
ISOQAR certified Management System, awarded to Emerald for adherence to

Environmental standard ISO 14001:2004.

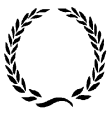

INVESTOR IN PEOPLE 


\section{CONTENTS}

Acknowledgments

vii

About the Author

ix

1. The Realignment of American Politics

2. Leadership, Motivation, and Social Identity 25

3. The American Revolution to the Mexican War 47

4. Republicans for Racial Justice: Abraham Lincoln and Ulysses S. Grant

5. The Republican Retreat from Founding Principles: 1877-1920

6. Migration and Realignment:

African-Americans Move North, the GOP Moves South

7. Popular Vote Tectonics: Republican Domination Gives Way to Democrats

References

Index 


\section{ACKNOWLEDGMENTS}

I am grateful to many people who have supported and sustained my interest in political history and presidential leadership. At the University of Richmond, I especially appreciate the discussions I've had with Scott Allison, Julian Hayter, and Daniel Palazzolo. Two wonderful students, Abby Huth and Matt Logan, were especially helpful. My confidants Stephen Hayes and Steve Young have consistently offered encouragement, and most important they have listened. Jim Shaw's occasional interruptions have always been refreshing. Family and friends at Raquette Lake provide the buoyancy needed to carry on. Thank you.

Elizabeth DeBusk-Maslanka has unfailingly provided cheerful editorial advice, research, and organization. I am deeply indebted to her. Other sustaining support has been offered by my colleagues Michele Bedsaul, Shannon Best, Jessica Flanigan, Javier Hidalgo, Crystal Hoyt, Don Forsyth, Peter Kaufman, Pam Khoury, Gary McDowell, Sandra Peart, Terry Price, Susan Taylor, Stephanie Trent, and Thad Williamson.

At Emerald, I want to thank Charlotte Maiorana for her initial interest in this project, and her support throughout. Also, Nick Wolterman has effectively guided the book through the production process, and I am grateful. 
Members of my family help tremendously by who they are, and by their wise understanding, especially Jefferson, Meagan, Andrew, and Vanessa. Most of all, I thank BB for her interest and support every single day. And truly, Tennyson Rose lights up my life. I am grateful for her timely arrival. 


\section{ABOUT THE AUTHOR}

George R. Goethals holds the E. Claiborne Robins Distinguished Professorship in Leadership Studies at the University of Richmond, Virginia. Previously at Williams College, he served as Chair of the Department of Psychology, Founding Chair of the Program in Leadership Studies, and Provost. With Georgia Sorenson and James MacGregor Burns, he edited the Encyclopedia of Leadership (2004). His recent scholarship explores rooting for the underdog, image-making in presidential debates, and the presidency of Ulysses S. Grant. 